Vol. 7(1), pp. 007-022, January, 2018

Copyright $\odot 2018$, the copyright of this article is retained by the author(s)

http://gjournals.org/GJEMPS

\title{
The Determinants and Predictive Components of the Willingness to Pay for Water and Water-Related Services in Bui Division, North West Region of Cameroon
}

\section{Dr. Robert Njilla Mengnjo Ngalim}

\author{
Department of Geography, FSMS, University of Buea, Cameroon
}

ARTICLE INFO

Article No.: 032217043

DOI: 10.15580/GJEMPS.2018.1.032217043

Submitted: $22 / 03 / 2017$

Accepted: $27 / 03 / 2017$

Published: 31/01/2018

${ }^{*}$ Corresponding Author

Robert Njilla Mengnjo Ngalim

E-mail: njillamn@yahoo.com

Phone: (+237) 677202989

Keywords: Determinants, Predictive

Components, Willingness to Pay,

Water, Bui Division, Cameroon
The study investigated the predictive components and determinants of the willingness to pay for water and water-related services in Bui Division, North West Region of Cameroon using the logistic regression modelling approach. Methods of data analyses involved the use of descriptive statistics (be specific in this case) and the Logistic Regression Modelling Technique for the households sampled. A total of 460 questionnaires were administered to heads of household in 120 villages and communities. Fifty one (51.35) percent of households sampled were between 21 and 40 years while the average age was 43 years. The educational level among the households sampled is high with 87.3 percent having post secondary school education. This perhaps influenced their willingness to pay for improved water supply service since education is expected to make the mind more receptive to innovation. The findings revealed that $35 \%$ of the total population of Bui Division paid nothing for water per month, while $34.1 \%$ paid between 100FCFA and 500FCFA per month for this water. This means that about $70 \%$ of the total population of Bui Division pay less than 500FCFA (\$1US) for water per month. 


\section{INTRODUCTION}

According to the Education for Sustainable Development Innovations by the MESA (Mainstreaming Environment and Sustainability in Africa) Universities Partnership through the Global University Network for Innovation, water is a driving force for sustainable development. Globally, for the total $100 \%$ of water on the planet earth, $97.5 \%$ is salt water while $2.5 \%$ is fresh water. For the total fresh water of $2.5 \%, 68.7 \%$ is locked in glaciers (thus, not available for human use), $30.1 \%$ as ground water and only $1.2 \%$ as surface and atmospheric water. Of the $1.2 \%$ of surface and atmospheric water, $67.4 \%$ is found in fresh water lakes, $12.2 \%$ as soil moisture, $9.5 \%$ in the atmosphere, $8.5 \%$ as wetlands, $1.6 \%$ in rivers and $0.8 \%$ as biota (United Nations, 2003). It is vital to all living organisms and ecosystems, and essential for human health, food production, social and economic development. Human and natural forces such as pollution, population growth, over-consumption, poor water management, deforestation and climate change are factors which further reduce both the quantity and quality of available water. It is estimated that if current trends continue, two out of every three people on earth will suffer moderate to severe water shortages by 2025 (UNDP, 2003; 2006).

Today, the world faces the problem of good governance: equitable sharing of water or "white gold", while ensuring the sustainability of natural ecosystems. At this point in time, humankind has not yet achieved this balance. For example, of the above seven billion people in the world, at least 1.2 billion do not have access to safe drinking water; more than 2.4 billion people do not have proper sanitation facilities, and more than 2.2 million people die (mostly infants and children between zero to five years) each year from preventable diseases caused by polluted water and poor sanitation conditions (UNDP, 2003; 2006; UNEP, 2012). Water availability and distribution has thus been an issue of the United Nations in its Millennium Development Goals. While there are huge reserves of underground and surface water resources which could be harnessed as potable water, many communities in Bui Division of the North West Region of Cameroon in particular (GP-DERUDEP, 2006; Fondufe, 2008; Tume, 2008; Njilla, 2010; Mbiydzenyuy, 2011), Cameroon in general (Ministry of Water Resources and Energy Report, 2010 ; Cameroon Vision 2035) and the world at large (ADB/ADF, 2000; UNDP, 2003; 2006, UNEP, 2012) cannot boast of safe drinking water, even in the second decade of the $21^{\text {st }}$ Century. This problem arises from the lack of optimisation of the various water resource opportunities, managerial problems, as well as the influence of rapidly increasing population, which is pushing mankind beyond the sustainable limits of all natural resources, and water inclusive (Njilla, 2015).

\section{THE PROBLEM AND OBJECTIVES}

The global water scarcity and sanitation situation implies that communities and nations have to do a lot to ensure that adequate quantities of water are provided to the population at appropriate quality standards. Due to the inherent problems encountered by the state in the provision of water to the population caused by increased state involvement in other developmental projects, it was necessary for communities to play an active role in water provision and management. The community involvement (participation) paradigm was officially adopted by the international community during the 1977 World Water Conference in Mar del Plata, Argentina. The Conference adopted a declaration in which it announced the International Drinking Water Supply and Sanitation Decade (IDWSSD) with the slogan "Water and Sanitation for All'. The Conference recognised that to come close to accomplishing this goal of "Water and Sanitation for All, a "radical overhaul of precepts and investment strategies governing the proliferation of taps, pumps and pipes in the developing world" was required (Black, 1998). To meet the above targets and objectives of the Slogan, there was the need for communities to pay for water-related infrastructural development by causing individuals to pay for water and water-related services. This was to achieve two main goals: the need to constantly provide water to the population and the maintenance of depreciated water-related infrastructures. There were, however, inherent problems of paying for water and water-related services since in the most part water was still perceived to be a social good and its provision the sole responsibility of the state. This then brought forward the concept of paying for water and willingness to pay for water. Therefore, the willingness to pay is the maximum amount of money that the consumer would give up in order to enjoy an improvement in water quality and service delivery (Haq, et al. 2007). The level of payment for water is directly proportional to financing of urban water supply infrastructural development (Whittington, et al., 1987, 1991). The willingness to pay could be over-estimated by private sector and under-estimated by government agency (Rogerson, 1996). However, the willingness to pay at the household level could be affected by access to other alternative water sources which are reliable than the public water utility system (Littlefair, 1998; Ayanshola et al, 2013).

The growing demand for water and the increasing need to meet this demand means that strategies must be put in place to ensure that water is supplied to the population. These strategies include structural and non-structural measures. Structural measures include the supply-augmentation strategies such as increasing the supply of water at the level of the watersheds and catchments, the construction of water schemes with proper systems of tanks, reservoirs and stand taps at appropriate localities. This therefore implies that adequate infrastructural development is required. The provision of the much needed waterrelated infrastructure demands huge investment on the part of the state and/or the communities concerned. It therefore follows that the population has to pay for water and water-related services if they have to continue to enjoy access to potable water. The problem arises from the fact that the population actually pays little or nothing for water, yet, they expect that adequate water is provided to them. Therefore, in the context of Bui 
Division, the need to augment the willingness to pay for water stems from the fact that the population wants to and desires to enjoy good quality water, appropriate financing and provision of water supply related infrastructure and constant access to potable water.

This study therefore investigates the determinants and predictive components of the willingness to pay for water and water-related services in Bui Division, North West Region of Cameroon. Specifically, it examines the demographic and socioeconomic data, development index categories, the distance and time required to fetch water from the sources, the perceptions of the population on willingness to pay for water, the actual amount paid for water and modelling of the willingness to pay for water using the Logistic Regression Modelling Approach.

\section{RESEARCH METHODS}

The standard social science methodology, which involves data collection, analysis and presentation of findings, discussions and conclusion was employed in this study. The sample size was estimated using Epi Info $6.04 \mathrm{~d}$ to be 443 . Considering a predicted percent of missing responses of at least $10 \%$, a total of 500 questionnaires were administered in this study.
Triangulation in sampling was considered and the following sampling techniques have been used in this study. The population-based survey was carried out in all the six (06) Sub-divisions of Bui Division, which included Kumbo Central, Nkum, Mbven (Mbiame), Dzekwa (Jakiri), Oku and Noni Sub-divisions. In order to ensure proper representation, the sample size was proportionately distributed according to the population weight of each of the sub-divisions. A total of 120 communities and villages with and without water schemes were therefore sampled in this study. In order for an in-depth study to be conducted taking into account all the variables, both quantitative and qualitative approaches were employed. The quantitative approach sought to yield quantifiable data in terms of numbers and measures that can permit statistical analysis, and measure the extent of validity and reliability of the study.

Another important primary data collection procedure was the administration of questionnaires. The questionnaire was semi-structured with both close - and open-ended questions. A total of 500 copies of the questionnaire were administered to inhabitants of the six sub-divisions that make up Bui Division (Table 1). The number of questionnaires for each sub-division was obtained based on the proportion of the population in each sub-division vis-à-vis the divisional total. The table also indicates the questionnaires returned per subdivision.

Table 1: Number of Questionnaires Administered and Returned per Sub-Division

\begin{tabular}{|l|l|l|l|l|l|}
\hline Sub-Divisions & $\begin{array}{l}\text { Population } \\
\text { size (2010) }\end{array}$ & $\begin{array}{l}\text { \% of } \\
\text { total }\end{array}$ & $\begin{array}{l}\text { Number of } \\
\text { questionnaires } \\
\text { administered }\end{array}$ & $\begin{array}{l}\text { Number of } \\
\text { questionnaires } \\
\text { returned }\end{array}$ & $\begin{array}{l}\% \text { of } \\
\text { total }\end{array}$ \\
\hline Kumbo Central (Kumbo) & 127,919 & 26.4 & 132 & 120 & 26.1 \\
\hline Nkum (Tatum) & 106,945 & 22.1 & 111 & 102 & 22.2 \\
\hline Mbven (Mbiame) & 48,684 & 10.1 & 50 & 45 & 9.8 \\
\hline Dzekwa (Jakiri) & 77,555 & 16.0 & 80 & 78 & 17.0 \\
\hline Oku (Elark) & 96,870 & 20.0 & 100 & 88 & 19.1 \\
\hline Noni (Djottin) & 26,112 & 05.4 & 27 & 27 & 5.9 \\
\hline Total & $\mathbf{4 8 4 , 0 8 5}$ & $\mathbf{1 0 0}$ & $\mathbf{5 0 0}$ & $\mathbf{4 6 0}$ & $\mathbf{1 0 0 . 0}$ \\
\hline
\end{tabular}

Source: Field work (2014)

In order to elaborately administer the questionnaires and obtain valuable information on which informed decisions could be based, the population of the study was divided into major stakeholders. These included: Managers of water management bodies and government officials (CAMWATER, Kumbo Water Authority and Council Authorities in charge of natural resources), Traditional Council members, caretakers of water catchments or schemes, presidents and members of Village Water Management Committees and the general public (consumers of water).

Data were analysed using descriptive statistics to present the distribution of subjects between and within subsets using frequencies and proportions, and more specifically Multiple Response Analysis (MRA) to compute aggregated score within conceptual components. Relationships between conceptual indicators and background indicators for categorical variables such as sex, age, level of educational attainment or income were appraised using the ChiSquare test of independence or equality of proportion for nominal-by-nominal and nominal-by-ordinal association or Somer's d for ordinal by ordinal association. Inter-item relationship or association were assessed using the nonparametric Spearman's Rho Test. The Logistic Regression Model was employed to appraise the effect of predictors on the dependent indicators. The explanatory powers of individual conceptual component were calculated as well as the Integrated Value Mapping (IVM) using Cox and Snell Pseudo R-Square. The effects of individual indicators were also appraised using the Log-Likelihood Ratio Test. All statistics were 
discussed at the 0.05 and 0.01 significant levels $(\alpha=$ 0.05 and $\alpha=0.01$ ). In the other sense, whenever the Pvalue was less than Alpha, there was a significant difference, a significant relationship, a significant dependence or association or a significant variability explained.

\section{FINDINGS AND DISCUSSIONS}

\subsection{The Demographic and Socio-Economic Data of Respondents}

In order to examine the willingness to pay for water and water-related services in Bui Division, it was important to discuss the socio-economic and demographic characteristics of the respondents. These factors are invaluable in establishing the trends and the situations of community water resource management in Bui Division.

In conducting the study, $55.4 \%$ of the respondents were males while $44.6 \%$ were females. This shows that the sample size was not gender biased. With regards to age range of the respondents, $28.4 \%$ were between 41 to 50 years, followed by those between 31 to 40 years $(24.8 \%) ; 21$ to 30 years, $(23.3 \%) ; 15$ to 20 years (11.5\%); 51 to 60 years $(6.1 \%)$ and above 60 years $(5.9 \%)$. This therefore means that the study considered the views and opinions of all the age groups. Concerning the marital status, $65.0 \%$ of the respondents were married and either heads of households or mothers, $29.8 \%$ were single, $3.5 \%, 1.1 \%$ and $0.7 \%$ were widows / widowers, divorced / separated and cohabiting respectively. This also shows that the opinions of the respondents were assessed based on their marital status. Those that were married had a family size of more than four (04) indicating a high demand for water. As far as the educational level was concerned, a majority of the respondents $57.2 \%$ had attended secondary / high school level, $30.2 \%$ had finished the primary school level, $8.9 \%$ had a Bachelor's degree and $1.1 \%$ had attended a master's degree. However, $2.6 \%$ had no formal education. This implies that the respondents understood well the subject matter under investigation.

Table 2 shows that $78.6 \%$ of respondents were involved in farming (50.8\%) and skilled workers (27.8\%). Traders / businesses represented $5.0 \%$ while students and the unemployed made up $12.8 \%$. The main occupation was then cross-tabulated with sub-divisions. Farming was most predominant in Mbven (Mbiame) Sub-division (95.6\%), followed by Nkum (60.4\%), Oku $(52.3 \%)$ and Noni (38.5\%) Sub-divisions. Skilled workers, traders / businesses, and students / unemployed were predominant in Kumbo Central Subdivision. It is important to note that farming takes place alongside other activities. With regard to annual income, a majority of the respondents $39.1 \%$ earned less than or equal to $100,000 \mathrm{FCFA}$ per year, $27.0 \%$ earned between 100,000 to $200,000 F C F A, 12.4 \%$ earned between 2001,000 to 400,000 FCFA, $8.9 \%$ earned between 400,001 to 600,000 FCFA while only $12.6 \%$ earned above 600,000FCFA.

Table 2: The Association of the Main Occupations and the Sub-Divisions

\begin{tabular}{|c|c|c|c|c|c|c|c|}
\hline \multirow[b]{2}{*}{ Sub-Divisions } & \multirow[b]{2}{*}{ Stats } & \multicolumn{5}{|c|}{ Main Occupations } & \multirow[b]{2}{*}{ Total } \\
\hline & & Farmer & Skilled worker & $\begin{array}{l}\text { Semi-skilled } \\
\text { worker }\end{array}$ & \begin{tabular}{|l|} 
Trader/ \\
Business
\end{tabular} & \begin{tabular}{|l|} 
Student/ \\
Unemployed
\end{tabular} & \\
\hline \multirow{2}{*}{ Kumbo Central } & n & 40 & 43 & 6 & 11 & 20 & 120 \\
\hline & $\%$ & $33.3 \%$ & $35.8 \%$ & $5.0 \%$ & $9.2 \%$ & $16.7 \%$ & $100.0 \%$ \\
\hline \multirow{2}{*}{ Nkum } & n & 61 & 23 & 3 & 3 & 11 & 101 \\
\hline & $\%$ & $60.4 \%$ & $22.8 \%$ & $3.0 \%$ & $3.0 \%$ & $10.9 \%$ & $100.0 \%$ \\
\hline \multirow{2}{*}{ Mbven } & n & 43 & 1 & 0 & 0 & 1 & 45 \\
\hline & $\%$ & $95.6 \%$ & $2.2 \%$ & $0 \%$ & $0 \%$ & $2.2 \%$ & $100.0 \%$ \\
\hline \multirow{2}{*}{ Jakiri } & n & 30 & 26 & 6 & 5 & 11 & 78 \\
\hline & $\%$ & $38.5 \%$ & $33.3 \%$ & $7.7 \%$ & $6.4 \%$ & $14.1 \%$ & $100.0 \%$ \\
\hline \multirow{2}{*}{ Oku } & $n$ & 45 & 24 & 1 & 4 & 12 & 86 \\
\hline & $\%$ & $52.3 \%$ & $27.9 \%$ & $1.2 \%$ & $4.7 \%$ & $14.0 \%$ & $100.0 \%$ \\
\hline \multirow{2}{*}{ Noni } & $n$ & 13 & 10 & 0 & 0 & 4 & 27 \\
\hline & $\%$ & $48.1 \%$ & $37.0 \%$ & $0 \%$ & $0 \%$ & $14.8 \%$ & $100.0 \%$ \\
\hline \multirow[t]{2}{*}{ Total } & $n$ & 232 & 127 & 16 & 23 & 59 & 457 \\
\hline & $\%$ & $50.8 \%$ & $27.8 \%$ & $3.5 \%$ & $5.0 \%$ & $12.9 \%$ & $100.0 \%$ \\
\hline
\end{tabular}

At this level, it was necessary to calculate the development index of the population of Bui Division using indicators such as age, marital status, educational level, occupation, annual income and socio-economic indicators such as ownership of a house, farm, cattle or livestock, television, a car or a bike (Table 3). This 
shows that $14.8 \%$ of the respondents had a development index in the category of very low, $48.9 \%$ in the low category, $16.1 \%$ in the high category and $20.2 \%$ in the very high category (Table 4). The overall conclusion is that a majority of the population falls within the very low and low development index categories $(63.7 \%)$. This has severe implications for water resources in the domain of paying for water and the procurement of private water connections.

Table 3: Computing the Development Index Categories

\begin{tabular}{|c|c|c|c|c|}
\hline Indicators & Stats & Frequency & Percent & Cumulative Percent \\
\hline \multirow{3}{*}{ Do you own a house? } & Yes & 330 & 71.7 & 71.7 \\
\hline & No & 130 & 28.3 & 100.0 \\
\hline & Total & 460 & 100.0 & \\
\hline \multirow{3}{*}{ Do you have a farm? } & Yes & 409 & 88.9 & 88.9 \\
\hline & No & 51 & 11.1 & 100.0 \\
\hline & Total & 460 & 100.0 & \\
\hline \multirow{3}{*}{ Do you have cattle or livestock? } & Yes & 230 & 50.0 & 50.0 \\
\hline & No & 230 & 50.0 & 100.0 \\
\hline & Total & 460 & 100.0 & \\
\hline \multirow{3}{*}{ Do you have a TV? } & Yes & 261 & 56.7 & 56.7 \\
\hline & No & 199 & 43.3 & 100.0 \\
\hline & Total & 460 & 100.0 & \\
\hline \multirow{3}{*}{ Do you have a car? } & Yes & 36 & 7.8 & 7.8 \\
\hline & No & 424 & 92.2 & 100.0 \\
\hline & Total & 460 & 100.0 & \\
\hline \multirow{3}{*}{ Do you have a bike? } & Yes & 118 & 25.7 & 25.7 \\
\hline & No & 342 & 74.3 & 100.0 \\
\hline & Total & 460 & 100.0 & \\
\hline
\end{tabular}

Source: Field work (2014)

Table 4: The Distribution of Development Index Categories by Sub-Divisions

\begin{tabular}{|c|c|c|c|c|c|c|}
\hline \multirow{2}{*}{ Sub-divisions } & \multirow{2}{*}{ Stats } & \multicolumn{4}{|c|}{ Development Index Categories } & \multirow{2}{*}{ Total } \\
\hline & & Very low & Low & High & Very high & \\
\hline \multirow{2}{*}{ Kumbo Central } & $\mathrm{n}$ & 18 & 46 & 21 & 35 & 120 \\
\hline & $\%$ & $15.0 \%$ & $38.3 \%$ & $17.5 \%$ & $29.2 \%$ & $100.0 \%$ \\
\hline \multirow{2}{*}{ Nkum } & $\mathrm{n}$ & 15 & 57 & 12 & 18 & 102 \\
\hline & $\%$ & $14.7 \%$ & $55.9 \%$ & $11.8 \%$ & $17.6 \%$ & $100.0 \%$ \\
\hline \multirow{2}{*}{ Mbven } & $\mathrm{n}$ & 5 & 32 & 6 & 2 & 45 \\
\hline & $\%$ & $11.1 \%$ & $71.1 \%$ & $13.3 \%$ & $4.4 \%$ & $100.0 \%$ \\
\hline \multirow{2}{*}{ Jakiri } & $\mathrm{n}$ & 13 & 31 & 15 & 19 & 78 \\
\hline & $\%$ & $16.7 \%$ & $39.7 \%$ & $19.2 \%$ & $24.4 \%$ & $100.0 \%$ \\
\hline \multirow{2}{*}{ Oku } & $n$ & 15 & 42 & 16 & 15 & 88 \\
\hline & $\%$ & $17.0 \%$ & $47.7 \%$ & $18.2 \%$ & $17.0 \%$ & $100.0 \%$ \\
\hline \multirow{2}{*}{ Noni } & $n$ & 2 & 17 & 4 & 4 & 27 \\
\hline & $\%$ & $7.4 \%$ & $63.0 \%$ & $14.8 \%$ & $14.8 \%$ & $100.0 \%$ \\
\hline \multirow{2}{*}{ Total } & $n$ & 68 & 225 & 74 & 93 & 460 \\
\hline & $\%$ & $14.8 \%$ & $48.9 \%$ & $16.1 \%$ & $20.2 \%$ & $100.0 \%$ \\
\hline
\end{tabular}

$x^{2}$-test: $X^{2}=27.054 ; d f=15 ; P=0.028$. Source: Field work (2014)

There was statistically a significant difference in the development index categories between the sub-divisions $(P=0.028)$ with Kumbo Central having the majority of those in the high and very high categories $(17.5 \%$ and 2 $9.2 \%$ respectively). This is because Kumbo Central doubles as the headquarters of Kumbo Central Subdivision and Bui Division as a whole. Noni and Nkum Sub-divisions have the majority of the population in the categories of very low and low because these are predominantly rural agricultural areas. In terms of sub- 
divisions, Nkum and Mbven have the lowest development indices because these are predominantly rural settlements characterised by intensive farming with the proceeds mostly sold to middle men for transportation to the urban centres or sub-divisional headquarters. This measure is therefore an important determinant of the willingness and ability to pay for water and water-related services since a lower and very low development indices imply less income devoted to the payment of or procurement of private home water connections.

\subsection{The Distance of the Water Source from the House}

One of the predictive components and determinants of the willingness to pay for water was the distance of the water source from the house. With regard to the distance covered to fetch water for those without private home connections, $44.6 \%$ have their water sources less than $1 \mathrm{~km}$ from their dwellings, $32.5 \%$ between $1-1.9 \mathrm{~km}$, $11.8 \%$ between 2 to $2.9 \mathrm{~km}, 3.8 \%$ between 3 to $3.9 \mathrm{~km}$ and $7.3 \%$ between 4 to $8 \mathrm{~km}$ (Table 5 ). This therefore shows that $55.4 \%$ of the population trek for more than $1 \mathrm{~km}$ to fetch water. This means that the coverage of or access to water is poor when compared to the United Nations estimates that potable water is considered appropriate when it is within $200 \mathrm{~m}$ of the users' dwellings (UN, 2003). There was statistically a significant difference between sub-divisions and the distance of the water source from the house $(P=0.004)$ with the populations of Nkum (20.2\%) and Mbven (15.8\%) Subdivisions covering distances of above two kilometres to fetch water. The least distances $(<1 \mathrm{~km})$ were covered in Jakiri $(95.1 \%)$ and Kumbo Central Sub-divisions $(80.9 \%)$.

Table 5: Distance Covered to Fetch Water from the House per Sub-divisions

\begin{tabular}{|c|c|c|c|c|c|}
\hline \multirow[t]{2}{*}{ Sub-divisions } & \multirow[t]{2}{*}{ Stats } & \multicolumn{3}{|c|}{$\begin{array}{l}\text { Distance of water source from the house } \\
\text { categories }\end{array}$} & \multirow[t]{2}{*}{ Total } \\
\hline & & $<=1 \mathrm{~km}$ & $1.1-2 \mathrm{~km}$ & $>2 \mathrm{~km}$ & \\
\hline \multirow{2}{*}{ Kumbo Central } & $n$ & 38 & 8 & 1 & 47 \\
\hline & $\%$ & $80.9 \%$ & $17.0 \%$ & $2.1 \%$ & $100.0 \%$ \\
\hline \multirow{2}{*}{ Nkum } & $n$ & 54 & 13 & 17 & 84 \\
\hline & $\%$ & $64.3 \%$ & $15.5 \%$ & $20.2 \%$ & $100.0 \%$ \\
\hline \multirow{2}{*}{ Mbven } & $n$ & 29 & 3 & 6 & 38 \\
\hline & $\%$ & $76.3 \%$ & $7.9 \%$ & $15.8 \%$ & $100.0 \%$ \\
\hline \multirow{2}{*}{ Jakiri } & $n$ & 39 & 0 & 2 & 41 \\
\hline & $\%$ & $95.1 \%$ & $0 \%$ & $4.9 \%$ & $100.0 \%$ \\
\hline \multirow{2}{*}{ Oku } & $n$ & 43 & 9 & 5 & 57 \\
\hline & $\%$ & $75.4 \%$ & $15.8 \%$ & $8.8 \%$ & $100.0 \%$ \\
\hline \multirow{2}{*}{ Noni } & $n$ & 12 & 5 & 2 & 19 \\
\hline & $\%$ & $63.2 \%$ & $26.3 \%$ & $10.5 \%$ & $100.0 \%$ \\
\hline \multirow{2}{*}{ Total } & $n$ & 215 & 38 & 33 & 286 \\
\hline & $\%$ & $75.2 \%$ & $13.3 \%$ & $11.5 \%$ & $100.0 \%$ \\
\hline
\end{tabular}

\subsection{The Time Taken to Fetch Water from the Source}

With respect to the time taken to fetch water from the source, $47.7 \%$ indicated that less than 1 hour was required, $42.8 \%$ indicated between 1 to 1.5 hours, $7.7 \%$ indicated 2 hours while $2.8 \%$ indicated above 3 hours (Table 6). This therefore shows that $52.3 \%$ of the population used more than one hour to fetch and cart water from their sources. This is valuable time which could be put into other productive ventures. There was also a statistically significant difference between the subdivisions and the time taken to fetch water from the source $(P=0.048)$ with Mbven (15.8\%) and Kumbo Central (14.9\%) Sub-division requiring above one and a half hour to fetch water. Kumbo Central and Mbven had the highest proportion of people with time to fetch water more than an hour and half, Kumbo Central because of the waiting in long queues and Mbven because of the distance covered to the water points. The least time was required in Jakiri (97.6\%), Oku (93.0\%) and Noni (89.5\%) Sub-divisions. There is also an association between distance of the water source from the house and how long it takes to fetch water from the source, meaning that the farther the distance, the more the time required to fetch water from that source. This view is supported by the findings of Adepoju \& Omonoma (2009) in Oshogbo Metropolis Nigeria, Ifabiyi (2011) in Ilorin, Kwara State, Nigeria, and Zelalem \& Beyene (2012) in the Goro-Guta District of Eastern Ethiopia. It therefore means that the distance and time taken to fetch water from the source have social, economic and health implications on the population and therefore are major determinants of the willingness to pay for water and improved water services. 
Table 6: The Time Taken to fetch Water from the Source

\begin{tabular}{|l|l|l|l|l|l|}
\hline \multirow{2}{*}{ Sub-Divisions } & \multirow{2}{*}{ Stats } & Time to fetch water & \multirow{2}{*}{ Total } \\
\cline { 3 - 7 } & & Up to 1 hour & More than 1 hour up to 1.5 hours & More than an hour and half & \\
\hline \multirow{2}{*}{ Kumbo Central } & $\mathrm{n}$ & 35 & 5 & 7 & 47 \\
\cline { 2 - 6 } & $\%$ & $74.5 \%$ & $10.6 \%$ & $14.9 \%$ & $100.0 \%$ \\
\hline \multirow{2}{*}{ Nkum } & $\mathrm{n}$ & 68 & 6 & 10 & 84 \\
\cline { 2 - 6 } & $\%$ & $81.0 \%$ & $7.1 \%$ & $11.9 \%$ & $100.0 \%$ \\
\hline \multirow{2}{*}{ Mbven } & $\mathrm{n}$ & 31 & 1 & 6 & 38 \\
\cline { 2 - 6 } & $\%$ & $81.6 \%$ & $2.6 \%$ & $15.8 \%$ & $100.0 \%$ \\
\hline \multirow{2}{*}{ Jakiri } & $\mathrm{n}$ & 40 & 0 & 1 & 41 \\
\cline { 2 - 6 } & $\%$ & $97.6 \%$ & $0 \%$ & $3.4 \%$ & $100.0 \%$ \\
\hline \multirow{2}{*}{ Nonu } & $\mathrm{n}$ & 53 & 1 & $5.3 \%$ & 57 \\
\cline { 2 - 6 } & $\%$ & $93.0 \%$ & $1.8 \%$ & 2 & $100.0 \%$ \\
\hline \multirow{2}{*}{ Total } & $\mathrm{n}$ & 17 & 0 & $10.5 \%$ & 19 \\
\cline { 2 - 6 } & $\%$ & $89.5 \%$ & $0 \%$ & 29 & $100.0 \%$ \\
\hline & $\mathrm{n}$ & 244 & 13 & $10.1 \%$ & $100.0 \%$ \\
\hline
\end{tabular}

Using the Spearman's rho correlation coefficient at the 0.01 level (2-tailed test) there was statistically a significant strong positive correlation between the distance of the water source from the house and the time it took to fetch water from this source with a correlation coefficient of $0.838(83.8 \%)$. This implies that the farther the distance of the water source from the house, the more the time required to fetch water. It was also necessary to examine the association between the sources of water and the time taken to fetch water from these sources (Table 7), as a determinant of the willingness to pay for water.

Table 7: The Association between Source of Water and Time to Fetch Water

\begin{tabular}{|c|c|c|c|c|c|}
\hline \multirow{2}{*}{$\begin{array}{l}\text { What is the source of } \\
\text { your drinking water? }\end{array}$} & \multirow{2}{*}{ Stats } & \multicolumn{3}{|c|}{ Time to fetch water } & \multirow{2}{*}{ Total } \\
\hline & & Up to 1 hour & More than 1 hour up to 1.5 hours & More than an hour and half & \\
\hline \multirow[t]{2}{*}{ Public tap } & $n$ & 184 & 11 & 21 & 216 \\
\hline & $\%$ & $85.2 \%$ & $5.1 \%$ & $9.7 \%$ & $100.0 \%$ \\
\hline \multirow[t]{2}{*}{ Private home connection } & $n$ & 2 & 0 & 0 & 2 \\
\hline & $\%$ & $100.0 \%$ & $0 \%$ & $0 \%$ & $100.0 \%$ \\
\hline \multirow[t]{2}{*}{ Streams } & $n$ & 42 & 2 & 6 & 50 \\
\hline & $\%$ & $84.0 \%$ & $4.0 \%$ & $12.0 \%$ & $100.0 \%$ \\
\hline \multirow[t]{2}{*}{ Springs } & $n$ & 9 & 0 & 2 & 11 \\
\hline & $\%$ & $81.8 \%$ & $0 \%$ & $18.2 \%$ & $100.0 \%$ \\
\hline \multirow[t]{2}{*}{ Bore holes } & $n$ & 2 & 0 & 0 & 2 \\
\hline & $\%$ & $100.0 \%$ & $0 \%$ & $0 \%$ & $100.0 \%$ \\
\hline \multirow[t]{2}{*}{ Wells } & $n$ & 5 & 0 & 0 & 5 \\
\hline & $\%$ & $100.0 \%$ & $0 \%$ & $0 \%$ & $100.0 \%$ \\
\hline \multirow[t]{2}{*}{ Total } & $n$ & 244 & 13 & 29 & 286 \\
\hline & $\%$ & $85.3 \%$ & $4.5 \%$ & $10.1 \%$ & $100.0 \%$ \\
\hline
\end{tabular}

$X^{2}$-test: $X^{2}=3.160 ; d f=10 ; P=0.977$. Source: Field work (2014)

The study revealed that the time taken to fetch water did not really depend on the source of water. It was expected that those who fetched water from streams or springs should obviously spend more time but paradoxically it was realised that $9.7 \%$ of those who fetched tap water also spent more than an hour and half to fetch water as compared to those who fetched water from streams $(P=0.977)$. If in the latter the time spent was explained by the distance of the source from the house, in the former, the long waiting because the taps were overcrowded was responsible for the time spent in fetching water from the source.

\section{PERCEPTIONS ABOUT THE WILLINGNESS TO PAY FOR WATER}

In evaluating the willingness to pay for water, it was important to establish the perceptions of the population about how much is paid for water and how they view this 
amount. This is important as there was a high positive perception of the willingness to pay for water, but the actual amount the population was willing to pay for water was minimal. This is still rooted in their perceptions that water is a free gift of nature, a social good which ought not to be paid for.

The willingness to pay for water is determined by the perceptions of the population about water resources in general. Eight indicators were chosen to assess the level of the willingness to pay for water by the population.

On the options "I am willing to pay for water because it is the right thing to do" (76.6\%); "I am willing to pay for water because it limits the time I spend fetching water" (85.7\%); "I am willing to pay for water because I am sure of the quality" $(77.9 \%)$, a majority of the respondents agreed (above 75\%). This therefore means that the population is aware of the importance of water and are willing to pay for water services without coercion. On the other hand, on the options "I do not pay much attention to issues related to conserving water", "there is much water, so I do not bother to minimise wastage", "water is cheap, so I do not bother to minimise wastage" and "conserving water at my home should be voluntary", $78.5 \%$ disagreed. These are important factors when establishing the predictive components of the willingness to pay for water, since a positive perception does not necessarily translate to a high ability to pay for water and water-related services.

Furthermore, on the options "I am willing to pay for water because I am told by the water management committee members to do so" (34.2\%); "I am willing to pay for water because I am told by my neighbours to do so" $(9.9 \%)$, "I am willing to pay for water only if water is brought to my home (40.6\%), "I am willing to pay for water because it is brought closer to my home" (46.1\%)", an overwhelming majority of the respondents disagreed, further justifying the fact that the willingness to pay for water is not by coercion. This could mean that the authorities in charge of water do not use all the means at their disposal to cause or instigate the population to pay for water. Therefore, with such positive perceptions about the willingness to pay for water, and the fact that the population does not actually want to pay for water, it becomes the question of implementation of the water regulation laws and the ability to pay, since a majority of the population falls within the very low and low development index categories.

Generally, the population of Bui Division expressed their willingness to pay for water (MRS: $71.1 \% ; n_{\text {responses }}=2359 ; x^{2}=1184.10 ; p<0.001$ ) (Table 8) and this willingness was not depended on any of the background indicators. If this information is corroborated with the amount paid, it can be resolved that the issue is not the willingness to pay, but the actual amount the population is willing to pay. This is supported by the positive correlation between the amount paid for water and the development index, with people in the higher development index categories paying higher for water and complaining the least about the cost of water. The reverse is true for those in the lower development index categories who pay less for water, yet complain the most.

\section{THE COST OF WATER}

After discussing the willingness to pay for water, it was important to examine the cost of water or the actual amount the population pays for water, so as to compare the willingness to pay for water and what is actually paid for water. Table 9 indicates that $34.6 \%$ of the population does not pay any amount for water, $33.7 \%$ paying between 100 to 500FCFA per month for water, and $10.0 \%$ pay between 600 to 1000FCFA. This therefore means that overall, $79.3 \%$ of the population of Bui Division pays less than 1,000FCFA (less than \$US2) for water usage per month. This amount is for those who pay monthly bills. However, for those who pay annual contributions, the amounts range from 300FCFA to $3,500 F C F A$ per year. This is grossly inadequate if the population should be supplied with the desired waterrelated infrastructures that will bring about adequate quantity and quality of water at appropriate times.

Table 8: Cross Tabulation of Indicators of Perceptions about Willingness to Pay for Water with Demographic / Socio-Economic Indicators in Bui Division

\begin{tabular}{|c|c|c|c|c|c|}
\hline \multirow{2}{*}{\multicolumn{2}{|c|}{ The Willingness to pay for water }} & \multicolumn{2}{|l|}{ Responses } & \multirow{2}{*}{$\mathrm{N}$} & \multirow{2}{*}{$\mathrm{X}^{2}$-test } \\
\hline & & Agreed & Disagreed & & \\
\hline \multirow{2}{*}{ Sex } & Male & $1458(71.5 \%)$ & $882(28.5 \%)$ & 2040 & \multirow{2}{*}{$\begin{array}{l}x^{2}=0.79 \\
p=0.374\end{array}$} \\
\hline & Female & $1151(70.2 \%)$ & $489(29.8 \%)$ & 1640 & \\
\hline \multirow{5}{*}{ Sub-divisions } & Kumbo central & $662(69.0 \%)$ & $298(31.0 \%)$ & 960 & \multirow{5}{*}{$\begin{array}{l}x^{2}=6.74 \\
p=0.241\end{array}$} \\
\hline & Nkum & $567(69.5 \%)$ & $249(30.5 \%)$ & 816 & \\
\hline & Mbven & $254(70.6 \%)$ & $106(29.4 \%)$ & 360 & \\
\hline & Jakiri & $464(74.4 \%)$ & $160(25.6 \%)$ & 624 & \\
\hline & Oku & $508(72.2 \%)$ & $196(27.8 \%)$ & 704 & \\
\hline
\end{tabular}




\begin{tabular}{|c|c|c|c|c|c|}
\hline & Noni & $154(71.3 \%)$ & $62(28.7 \%)$ & 216 & \\
\hline \multirow{3}{*}{$\begin{array}{l}\text { Highest Level of } \\
\text { Educational } \\
\text { Attainment }\end{array}$} & $\begin{array}{l}\text { No formal education and } \\
\text { primary }\end{array}$ & $835(69.1 \%)$ & $373(30.9 \%)$ & 1208 & \multirow{3}{*}{$\begin{array}{l}x^{2}=2.88 \\
p=0.237\end{array}$} \\
\hline & Secondary/high school level & $1508(71.7 \%)$ & $596(28.3 \%)$ & 2104 & \\
\hline & Tertiary education & $266(72.3 \%)$ & $102(27.7 \%)$ & 368 & \\
\hline \multirow{6}{*}{ Age range } & $15-20$ year & $309(72.9 \%)$ & $115(27.1 \%)$ & 424 & \multirow{6}{*}{$\begin{array}{l}x^{2}=2.35 \\
p=0.799\end{array}$} \\
\hline & $21-30$ years & $607(70.9 \%)$ & $249(29.1 \%)$ & 856 & \\
\hline & $31-40$ years & $640(70.2 \%)$ & $272(28.8 \%)$ & 912 & \\
\hline & $41-50$ years & $740(70.6 \%)$ & $308(29.4 \%)$ & 1048 & \\
\hline & $51-60$ years & $154(68.8 \%)$ & $70(31.3 \%)$ & 224 & \\
\hline & Above 60 years & $159(73.6 \%)$ & $57(26.4 \%)$ & 216 & \\
\hline \multirow{4}{*}{$\begin{array}{l}\text { Development } \\
\text { Index } \\
\text { Categories }\end{array}$} & Very low & $377(69.3 \%)$ & $167(30.7 \%)$ & 544 & \multirow{4}{*}{$\begin{array}{l}x^{2}=5.61 \\
p=0.132\end{array}$} \\
\hline & Low & $1269(70.5 \%)$ & $531(29.5 \%)$ & 1800 & \\
\hline & High & $443(74.8 \%)$ & $149(25.2 \%)$ & 592 & \\
\hline & Very high & $520(69.9 \%)$ & $224(30.1 \%)$ & 744 & \\
\hline \multirow{3}{*}{$\begin{array}{l}\text { Institution } \\
\text { responsible for } \\
\text { managing water }\end{array}$} & Kumbo Water Authority & $349(68.2 \%)$ & $163(31.8 \%)$ & 512 & \multirow{3}{*}{$\begin{array}{l}x^{2}=6.45 \\
p=0.040\end{array}$} \\
\hline & Village(rural) water scheme & $1957(71.3 \%)$ & $787(28.7 \%)$ & 2744 & \\
\hline & CAMWATER & $53(82.8 \%)$ & $11(17.2 \%)$ & 64 & \\
\hline \multicolumn{2}{|l|}{ Total (MRS) } & $\begin{array}{l}2359 \\
(71.1 \%)\end{array}$ & $961(28.9 \%)$ & 3320 & $\begin{array}{l}X^{2}=1184.10 \\
p<0.001\end{array}$ \\
\hline
\end{tabular}

Source: Generated from Questionnaire Analysis by Authors (August, 2014)

Table 9: Amount of Money Paid per Month for Water Use

\begin{tabular}{|l|l|l|l|l|}
\hline $\begin{array}{l}\text { How much do you pay for water each } \\
\text { month? }\end{array}$ & Frequency & Percent & $\begin{array}{l}\text { Valid } \\
\text { Percent }\end{array}$ & Cumulative Percent \\
\hline Nothing at all & 159 & 34.6 & 35.0 & 35.0 \\
\hline Between 100 and 500 FCFA & 155 & 33.7 & 34.1 & 69.2 \\
\hline Between 600 and 1,000 FCFA & 46 & 10.0 & 10.1 & 79.3 \\
\hline Between 1,100 and 1,500 FCFA & 31 & 6.7 & 6.8 & 86.1 \\
\hline Between 1,600 and 2,000 FCFA & 24 & 5.2 & 5.3 & 91.4 \\
\hline More than 2,000 FCFA & 39 & 8.5 & 8.6 & $\mathbf{1 0 0 . 0}$ \\
\hline Total & 454 & 98.7 & $\mathbf{1 0 0 . 0}$ & \\
\hline Missing & 6 & 1.3 & & \\
\hline Total & $\mathbf{4 6 0}$ & $\mathbf{1 0 0 . 0}$ & & \\
\hline
\end{tabular}

Source: Generated from Questionnaire Analysis by Author (August, 2014)

In relation to the opinions of the population on their perception of how much is paid for water, only $15.9 \%$ indicated that the amount was low, $53.1 \%$ indicated moderate and $25.5 \%$ indicated high. Using the Chisquare test at the 0.05 level of significance, there was statistically a significant difference between how much was paid for water each month and the perceptions

Table 10: The Association between How Much is Paid for Water each Month and Perception about the Amount

\begin{tabular}{|l|l|l|l|l|l|}
\hline \multirow{2}{*}{$\begin{array}{l}\text { How much do you pay for water each } \\
\text { month }\end{array}$} & \multirow{2}{*}{ stats } & \multicolumn{2}{l|}{ How is this amount to you? } & \multirow{2}{*}{ Total } \\
\cline { 3 - 6 } & & High & Moderate & Low & \\
\hline \multirow{2}{*}{ Nothing at all } & $\mathrm{n}$ & 3 & 0 & 44 & 47 \\
\cline { 2 - 6 } & $\%$ & $6.4 \%$ & $0 \%$ & $93.6 \%$ & $100.0 \%$ \\
\hline \multirow{2}{*}{ Between 100 and 500 FCFA } & $\mathrm{n}$ & 6 & 122 & 26 & 154 \\
\cline { 2 - 6 } & $\%$ & $3.9 \%$ & $79.2 \%$ & $16.9 \%$ & $100.0 \%$ \\
\hline Between 600 and 1,000 FCFA & $\mathrm{n}$ & 17 & 28 & 1 & 46 \\
\hline
\end{tabular}




\begin{tabular}{|l|l|l|l|l|l|}
\hline & $\%$ & $37.0 \%$ & $60.9 \%$ & $2.2 \%$ & $100.0 \%$ \\
\hline \multirow{2}{*}{ Between 1,100 and 1,500 FCFA } & $\mathrm{n}$ & 14 & 17 & 0 & 31 \\
\cline { 2 - 6 } & $\%$ & $45.2 \%$ & $54.8 \%$ & $0 \%$ & $100.0 \%$ \\
\hline \multirow{2}{*}{ Between 1,600 and 2,000 FCFA } & $\mathrm{n}$ & 16 & 8 & 0 & 24 \\
\cline { 2 - 6 } & $\%$ & $66.7 \%$ & $33.3 \%$ & $0 \%$ & $100.0 \%$ \\
\hline \multirow{2}{*}{ More than 2,000 FCFA } & $\mathrm{n}$ & 31 & 6 & 2 & 39 \\
\cline { 2 - 6 } & $\%$ & $79.5 \%$ & $15.4 \%$ & $5.1 \%$ & $100.0 \%$ \\
\hline \multirow{2}{*}{ Total } & $\mathrm{n}$ & 87 & 181 & 73 & 341 \\
\cline { 2 - 6 } & $\%$ & $25.5 \%$ & $53.1 \%$ & $21.4 \%$ & $100.0 \%$ \\
\hline
\end{tabular}

$X^{2}$-test: $X^{2}=300.485 ; d f=10 ; P<0.001$. Source: Generated from Questionnaire Analysis by Author (August, 2014)

Using the Spearman's rho correlation coefficient, there was a significant strong positive correction at the 0.01 level (2-tailed test) with a correlation coefficient of 0.707 $(70.7 \%)$ between how much is paid for water and the perceived opinions of how much is paid. That is, the higher the amount paid, the more people perceive the amount as being high. There was also an association between the sub-divisions and how much is paid for water, and this difference was statistically significant at the 0.05 level of significance $\left(x^{2}=242.486 ; p<0.001\right)$ (Table 11).

Table 11: The Association between Sub-Divisions and How Much is Paid for Water each Month

\begin{tabular}{|c|c|c|c|c|c|c|c|c|}
\hline \multirow[b]{2}{*}{ Sub- Divisions } & \multirow[b]{2}{*}{ Stats } & \multicolumn{6}{|c|}{ How much do you pay for water each month? } & \multirow[b]{2}{*}{ Total } \\
\hline & & $\begin{array}{l}\text { Nothing } \\
\text { at all }\end{array}$ & $\begin{array}{l}\text { Between } \\
100 \text { and } \\
500 \text { FCFA }\end{array}$ & $\begin{array}{l}\text { Between } 600 \\
\text { and } 1,000 \\
\text { FCFA }\end{array}$ & $\begin{array}{l}\text { Between } \\
1,100 \text { and } \\
1,500 \text { FCFA }\end{array}$ & $\begin{array}{l}\text { Between } \\
1,600 \text { and } \\
2,000 \text { FCFA }\end{array}$ & $\begin{array}{l}\text { More than } \\
2,000 \text { FCFA }\end{array}$ & \\
\hline \multirow{2}{*}{ Kumbo Central } & $n$ & 18 & 26 & 21 & 19 & 11 & 23 & 118 \\
\hline & $\%$ & $15.3 \%$ & $22.0 \%$ & $17.8 \%$ & $16.1 \%$ & $9.3 \%$ & $19.5 \%$ & $100.0 \%$ \\
\hline \multirow{2}{*}{ Nkum } & n & 42 & 33 & 12 & 3 & 3 & 8 & 101 \\
\hline & $\%$ & $41.6 \%$ & $32.7 \%$ & $11.9 \%$ & $3.0 \%$ & $3.0 \%$ & $7.9 \%$ & $100.0 \%$ \\
\hline \multirow{2}{*}{ Mbven } & $n$ & 44 & 0 & 0 & 0 & 1 & 0 & 45 \\
\hline & $\%$ & $97.8 \%$ & $0 \%$ & $0 \%$ & $0 \%$ & $2.2 \%$ & $0 \%$ & $100.0 \%$ \\
\hline \multirow{2}{*}{ Jakiri } & n & 5 & 59 & 4 & 1 & 2 & 6 & 77 \\
\hline & $\%$ & $6.5 \%$ & $76.6 \%$ & $5.2 \%$ & $1.3 \%$ & $2.6 \%$ & $7.8 \%$ & $100.0 \%$ \\
\hline \multirow{2}{*}{ Oku } & $n$ & 47 & 19 & 8 & 5 & 5 & 2 & 86 \\
\hline & $\%$ & $54.7 \%$ & $22.1 \%$ & $9.3 \%$ & $5.8 \%$ & $5.8 \%$ & $2.3 \%$ & $100.0 \%$ \\
\hline \multirow{2}{*}{ Noni } & $n$ & 3 & 18 & 1 & 3 & 2 & 0 & 27 \\
\hline & $\%$ & $11.1 \%$ & $66.7 \%$ & $3.7 \%$ & $11.1 \%$ & $7.4 \%$ & $0 \%$ & $100.0 \%$ \\
\hline \multirow{2}{*}{ Total } & $n$ & 159 & 155 & 46 & 31 & 24 & 39 & 454 \\
\hline & $\%$ & $35.0 \%$ & $34.1 \%$ & $10.1 \%$ & $6.8 \%$ & $5.3 \%$ & $8.6 \%$ & $100.0 \%$ \\
\hline
\end{tabular}

$X^{2}$-test: $X^{2}=242.486 ; d f=25 ; P<0.001$. Source: Generated from Questionnaire Analysis by Author (August, 2014)

Therefore, $97.8 \%$ of the population of Mbven and $54.7 \%$ of the population of Oku do not pay a dime for water, as these people depended mainly on open-sources of water such as springs, streams, rivers and boreholes. The population of Jakiri paid between 100 to 500FCFA (76.6\%) because besides CAMWATER there are several community water schemes in Jakiri Sub-division which provide water to the population; and in Noni $(66.7 \%)$. A majority of those that pay above 2000FCFA are found in Kumbo Central (19.5\%) and Nkum (7.9\%) Sub-divisions (Table 11).
Using the Chi-square test at the 0.05 level of significance, there was statistically a significant difference between the sub-divisions and the perceptions about this amount $\left(x^{2}=86.099 ; p<0.001\right)$, with $74.5 \%$ considering the amount paid for water to be low and moderate, while $25.5 \%$ viewed the amount as high. In terms of sub-divisions, a majority of the population of Mbiame consider the amount paid as low (88.2\%), $70.8 \%$ of the population of Noni, $66.7 \%$ of the population of Jakiri and $63.8 \%$ of the population of Oku perceived the amount as moderate while $43.4 \%$ and 
$45.8 \%$ of the population of Kumbo Central considered the amount as moderate and high respectively (Table

12).

Table 12: Association between Institutions Responsible for Managing and Distributing Water to the Population and How Much is Paid for Water each Month

\begin{tabular}{|c|c|c|c|c|c|c|c|c|}
\hline \multirow{2}{*}{$\begin{array}{l}\text { Which institution is } \\
\text { responsible for } \\
\text { managing and } \\
\text { distributing water to } \\
\text { the population in your } \\
\text { locality? }\end{array}$} & \multirow[b]{2}{*}{ Stats } & \multicolumn{6}{|c|}{ How much do you pay for water each month? } & \multirow[b]{2}{*}{ Total } \\
\hline & & $\begin{array}{l}\text { Nothin } \\
g \text { at all }\end{array}$ & $\begin{array}{l}\text { Between } \\
100 \text { and } \\
500 \text { FCFA }\end{array}$ & $\begin{array}{l}\text { Between } \\
600 \text { and } \\
1,000 \\
\text { FCFA }\end{array}$ & $\begin{array}{l}\text { Between } \\
1,100 \text { and } \\
1,500 \\
\text { FCFA }\end{array}$ & $\begin{array}{l}\text { Between } \\
1,600 \text { and } \\
2,000 \\
\text { FCFA }\end{array}$ & $\begin{array}{l}\text { More } \\
\text { than } \\
2,000 \\
\text { FCFA }\end{array}$ & \\
\hline \multirow{2}{*}{$\begin{array}{l}\text { Kumbo Water } \\
\text { Authority }\end{array}$} & $n$ & 2 & 6 & 14 & 13 & 8 & 20 & 63 \\
\hline & $\%$ & $3.2 \%$ & $9.5 \%$ & $22.2 \%$ & $20.6 \%$ & $12.7 \%$ & $31.7 \%$ & $\begin{array}{l}100.0 \\
\%\end{array}$ \\
\hline \multirow{2}{*}{$\begin{array}{l}\text { Village (rural) water } \\
\text { scheme }\end{array}$} & $n$ & 117 & 146 & 31 & 17 & 13 & 14 & 338 \\
\hline & $\%$ & $34.6 \%$ & $43.2 \%$ & $9.2 \%$ & $5.0 \%$ & $3.8 \%$ & $4.1 \%$ & $\begin{array}{l}100.0 \\
\%\end{array}$ \\
\hline \multirow[b]{2}{*}{ CAMWATER } & $n$ & 0 & 0 & 1 & 1 & 2 & 4 & 8 \\
\hline & $\%$ & $0 \%$ & $0 \%$ & $12.5 \%$ & $12.5 \%$ & $25.0 \%$ & $50.0 \%$ & $\begin{array}{l}100.0 \\
\%\end{array}$ \\
\hline \multirow[b]{2}{*}{ NGO } & $n$ & 1 & 1 & 0 & 0 & 0 & 0 & 2 \\
\hline & $\%$ & $50.0 \%$ & $50.0 \%$ & $0 \%$ & $0 \%$ & $0 \%$ & $0 \%$ & $\begin{array}{l}100.0 \\
\%\end{array}$ \\
\hline \multirow[b]{2}{*}{ Elite } & $n$ & 1 & 0 & 0 & 0 & 0 & 1 & 2 \\
\hline & $\%$ & $50.0 \%$ & $0 \%$ & $0 \%$ & $0 \%$ & $0 \%$ & $50.0 \%$ & $\begin{array}{l}100.0 \\
\%\end{array}$ \\
\hline \multirow[b]{2}{*}{ Total } & $n$ & 121 & 153 & 46 & 31 & 23 & 39 & 413 \\
\hline & $\%$ & $29.3 \%$ & $37.0 \%$ & $11.1 \%$ & $7.5 \%$ & $5.6 \%$ & $9.4 \%$ & $\begin{array}{l}100.0 \\
\%\end{array}$ \\
\hline
\end{tabular}

$X^{2}$-test: $X^{2}=141.418 ; d f=20 ; P<0.001$. Source: Generated from Questionnaire Analysis by Author (August, 2014)

There was also statistically a significant difference between the institutions responsible for managing and distributing water to the population and the perceptions about this amount $(p<0.001)$ (Table 13$)$, with a majority of the population using the Kumbo Water Authority paying between 1,000FCFA to above 2,000FCFA, while in Jakiri alone for those using CAMWATER 50\% paid above 2,000FCFA. In relation to village (rural) water schemes $34.6 \%$ paid nothing for water, $43.2 \%$ paid between 100 to 500FCFA, while only $4.1 \%$ paid above $2,000 F C F A$. For all the institutions responsible for managing water combined, $29.3 \%$ of the population paid nothing at all, 48.1\% paid between 100 and 1,000FCFA while $22.5 \%$ paid above 1,000 FCFA (Table 13 ).

Also, the amount paid for water was correlated with the development index categories and the findings revealed that $78.3 \%$ of those between the very low and low development index categories paid nothing for water on a monthly basis (Table 14). At the same time, 50.0\% of those in the high and very high development index categories did not have any monthly payments for water. This trend is a characteristic of village (rural) water schemes where annual levies ranging from 350FCFA to $5,000 F C F A$ are paid rather than monthly bills.

Table 13: Association between Institution Responsible for Managing and Distributing Water to the Population and Perception of the Amount Paid

\begin{tabular}{|c|c|c|c|c|c|}
\hline \multirow{2}{*}{$\begin{array}{l}\text { Which institution is responsible for managing } \\
\text { and distributing water to the population in your } \\
\text { locality? }\end{array}$} & \multirow{2}{*}{ Stats } & \multicolumn{3}{|c|}{ How is this amount to you } & \multirow{2}{*}{ Total } \\
\hline & & Low & Moderate & High & \\
\hline \multirow{2}{*}{ Kumbo Water Authority } & $\mathrm{N}$ & 0 & 21 & 40 & 61 \\
\hline & $\%$ & $0 \%$ & $34.4 \%$ & $65.6 \%$ & $100.0 \%$ \\
\hline Village (rural) water scheme & $\mathrm{N}$ & 62 & 156 & 38 & 256 \\
\hline
\end{tabular}




\begin{tabular}{|l|l|l|l|l|l|}
\hline & $\%$ & $24.2 \%$ & $60.9 \%$ & $14.8 \%$ & $100.0 \%$ \\
\hline \multirow{2}{*}{ CAMWATER } & $\mathrm{N}$ & 0 & 1 & 7 & 8 \\
\cline { 2 - 7 } & $\%$ & $0 \%$ & $12.5 \%$ & $87.5 \%$ & $100.0 \%$ \\
\hline \multirow{2}{*}{ NGO } & $\mathrm{N}$ & 0 & 1 & 0 & 1 \\
\cline { 2 - 7 } & $\%$ & $0 \%$ & $100.0 \%$ & $0 \%$ & $100.0 \%$ \\
\hline \multirow{2}{*}{ Elite } & $\mathrm{N}$ & 0 & 0 & 1 & 1 \\
\cline { 2 - 7 } & $\%$ & $0 \%$ & $0 \%$ & $100.0 \%$ & $100.0 \%$ \\
\hline \multirow{2}{*}{ Total } & $\mathrm{N}$ & 62 & 179 & 86 & 327 \\
\cline { 2 - 6 } & $\%$ & $19.0 \%$ & $54.7 \%$ & $26.3 \%$ & $100.0 \%$ \\
\hline
\end{tabular}

$X^{2}$-test: $X^{2}=89.391 ; d f=8 ; P<0.001$. Source: Generated from Questionnaire Analysis by Author (August, 2014)

Table 14: Association between Development Index Categories and How Much is Paid for Water each Month

\begin{tabular}{|c|c|c|c|c|c|c|c|c|}
\hline \multirow[b]{2}{*}{$\begin{array}{l}\text { Development } \\
\text { index categories }\end{array}$} & \multirow[b]{2}{*}{$\begin{array}{l}\text { Stat } \\
\text { S }\end{array}$} & \multicolumn{6}{|c|}{ How much do you pay for water each month? } & \multirow[b]{2}{*}{ Total } \\
\hline & & $\begin{array}{l}\text { Nothing } \\
\text { at all }\end{array}$ & $\begin{array}{l}\text { Between } \\
100 \text { and } \\
500 \text { FCFA }\end{array}$ & $\begin{array}{l}\text { Between } \\
600 \text { and } \\
1,000 \\
\text { FCFA }\end{array}$ & $\begin{array}{l}\text { Between } \\
1,100 \text { and } \\
1,500 \text { FCFA }\end{array}$ & $\begin{array}{l}\text { Between } \\
1,600 \text { and } \\
2,000 \\
\text { FCFA }\end{array}$ & $\begin{array}{l}\text { More than } \\
2,000 \\
\text { FCFA }\end{array}$ & \\
\hline \multirow{2}{*}{ Very low } & n & 24 & 26 & 4 & 7 & 5 & 2 & 68 \\
\hline & $\%$ & $35.3 \%$ & $38.2 \%$ & $5.9 \%$ & $10.3 \%$ & $7.4 \%$ & $2.9 \%$ & $100.0 \%$ \\
\hline \multirow{2}{*}{ Low } & $n$ & 95 & 71 & 20 & 10 & 10 & 15 & 221 \\
\hline & $\%$ & $43.0 \%$ & $32.1 \%$ & $9.0 \%$ & $4.5 \%$ & $4.5 \%$ & $6.8 \%$ & $100.0 \%$ \\
\hline \multirow{2}{*}{ High } & $n$ & 23 & 24 & 8 & 7 & 4 & 7 & 73 \\
\hline & $\%$ & $31.5 \%$ & $32.9 \%$ & $11.0 \%$ & $9.6 \%$ & $5.5 \%$ & $9.6 \%$ & $100.0 \%$ \\
\hline \multirow{2}{*}{ Very high } & n & 17 & 34 & 14 & 7 & 5 & 15 & 92 \\
\hline & $\%$ & $18.5 \%$ & $37.0 \%$ & $15.2 \%$ & $7.6 \%$ & $5.4 \%$ & $16.3 \%$ & $100.0 \%$ \\
\hline \multirow{2}{*}{ Total } & n & 159 & 155 & 46 & 31 & 24 & 39 & 454 \\
\hline & $\%$ & $35.0 \%$ & $34.1 \%$ & $10.1 \%$ & $6.8 \%$ & $5.3 \%$ & $8.6 \%$ & $100.0 \%$ \\
\hline
\end{tabular}

$X^{2}$-test: $X^{2}=30.592 ; d f=15 ; P=0.010$. Source: Generated from Questionnaire Analysis by Author (August, 2014)

Also, using the Spearman's rho correlation coefficient at the 0.01 level of significance (2-tailed test), there was a significant but weak positive correlation between how much is paid for water and development index (0.175), meaning that the willingness and ability to pay for water increased with an increase in the development index, that is, those of the highest development index were more willing and able to pay for water than those of the low development index. These findings revealed that the population generally was willing to pay for water. However, the amount they were willing to pay was very minimal. This is still rooted in their perceptions of water as a social good (free gift of nature) which should not be paid for and the fact that some of them do not have the ability to pay since a greater proportion of the population falls within the very low and low development indices.

\section{LOGISTIC REGRESSION MODEL}

The Logistic Regression Modelling technique was used to establish the predictors of the willingness to pay for water. This was aided by the use of the SPSS Version 21.0 and Epi Data software packages.

\subsection{Determining the Predictors of the Willingness to Pay for Water}

Since one of the major issues or challenges confronting community water management in Bui Division was empirically determined to be the willingness and ability to pay for water, it was important to determine the predictors of the willingness to pay for water. These predictive components are those indicators which if properly put in place, implemented and enhanced will cause a majority of the population to perceive water not only as a social good which ought to be free, but as an economic good which should be paid for. These predictive components were determined using the Omnibus Tests of Model Coefficients using the Chi- 
square level of significance and the Cox \& Snell $R$ these predictive components include the following (Table Square (Explanatory or Predictive Power). Some of 15).

Table 15: Predictive Components of the Willingness to Pay for Water

\begin{tabular}{|l|l|l|l|}
\hline Predictive components & $\begin{array}{l}\text { Omnibus Tests of Model } \\
\text { Coefficients (Chi-square } \\
\text { level of significance) }\end{array}$ & $\begin{array}{l}\text { Cox \& Snell R Square } \\
\text { (Explanatory Power or } \\
\text { Predictive Power) }\end{array}$ & $\mathbf{N}$ \\
\hline Socio-economic indicators & $\mathrm{P}=0.433$ & $2.0 \%$ & 460 \\
\hline $\begin{array}{l}\text { Indicators of access to water } \\
\text { (shortages of water) }\end{array}$ & $\mathrm{P}=0.396$ & $7.0 \%$ & 460 \\
\hline $\begin{array}{l}\text { Perception of water as economic } \\
\text { good that should be paid for }\end{array}$ & $\mathrm{P}<0.001$ & $9.7 \%$ & 460 \\
\hline $\begin{array}{l}\text { Willingness to conserve water } \\
\text { (Household water conservation) }\end{array}$ & $\mathrm{P}<0.001$ & $6.3 \%$ & 460 \\
\hline $\begin{array}{l}\text { Perception about water } \\
\text { management committees }\end{array}$ & $\mathrm{P}=0.003$ & $4.1 \%$ & 460 \\
\hline $\begin{array}{l}\text { Optimization strategies of } \\
\text { community water management }\end{array}$ & $\mathrm{P}=0.001$ & $7.3 \%$ & 460 \\
\hline Motivation to pay for water. & $\mathrm{P}<0.001$ & $9.4 \%$ & 460 \\
\hline IVM (Integrated Value Mapping) & $\mathrm{P}=0.148$ & $28.4 \%$ & 460 \\
\hline
\end{tabular}

The perception of water as an economic good, motivation to pay for water and the optimization of water management were the three major predictors of the willingness to pay for water as they had higher predictive power or EP (Explanatory Power). The IVM of $28.4 \%$ with almost $70 \%$ of variability not explained indicates that there are other important factors alongside those considered by this model that determine the willingness to pay for water. The socio-economic predictor had the lowest EP indicating that the problem of the lack of the willingness to pay is not related to socio-economic factors but are more of managerial and perception of water as gift that should not be paid for (Table 15) (Figure 1).

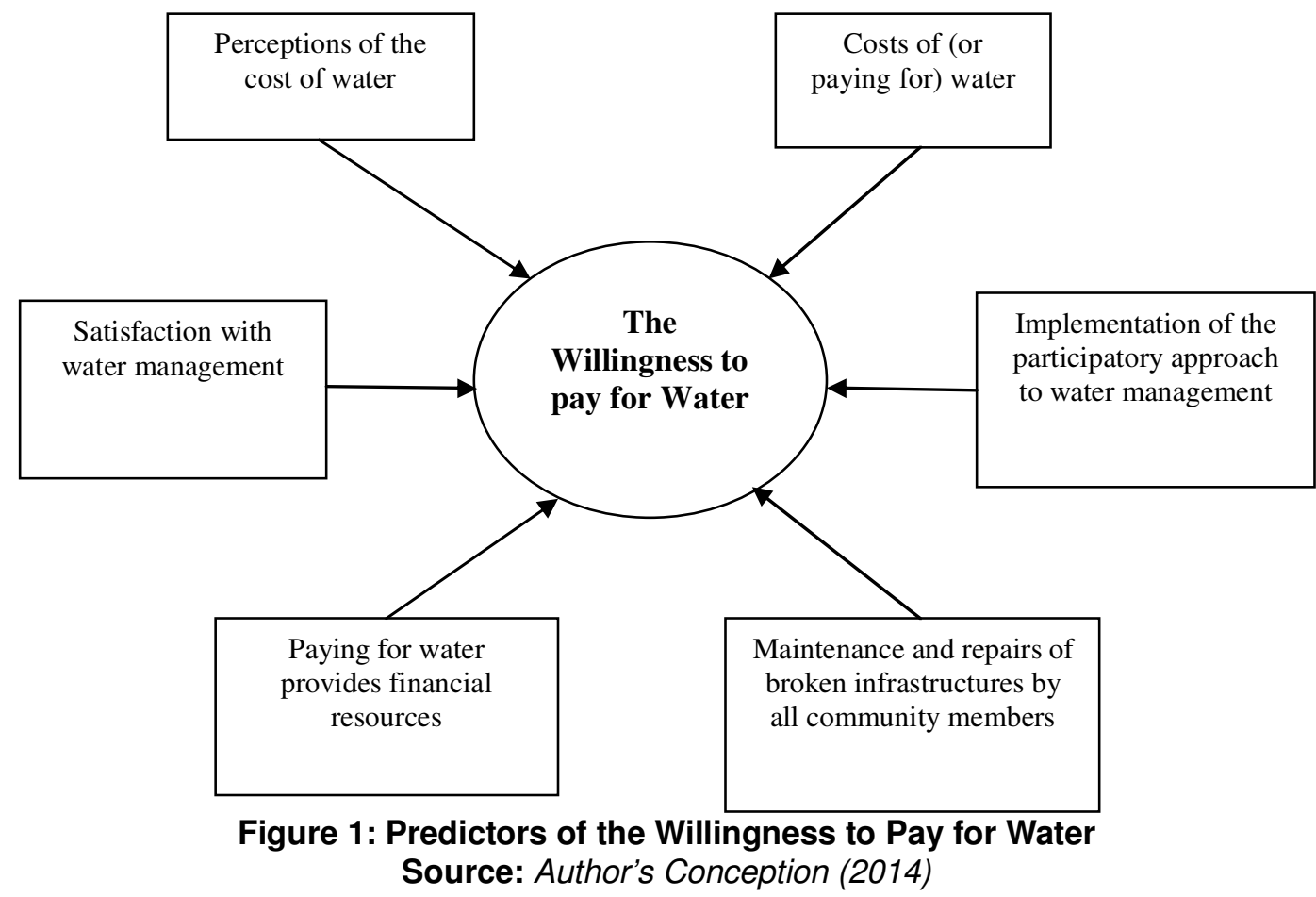


The Likelihood Ratio Test indicates that the following indicators significantly predict the willingness to pay (Figure 1). In the final analysis, the concept of Integrated Water Resources Management calibrated to mimic the local situation of Bui Division was deemed to be the proper mechanism through which water-related management problems could be tackled. This is because the concept takes into the consideration all the facets of issues affecting water management and the role of human activities in accentuating these problems. The concept also brings out the centrality of human beings in solving human-induced problems through better land use planning and control, proper institutional arrangements, stakeholder participation and concerted decision making.

\section{CONCLUSION}

This study has investigated the predictive components and determinants of the willingness to pay for water and water-related services in Bui Division, North West Region of Cameroon using multi-statistical analysis and the logistic regression modelling approaches. The findings revealed that the development index categories were important in determining the willingness to pay for water. The higher the development index, the higher the income of the population and the higher the willingness to pay for water. Also, the distance of the water sources from the house and the time it took to fetch water from these sources were major determinants of the willingness to pay for water. As such, the study area has witnessed an increase in stakeholder participation and participatory development in the water sector. This has been the basis for the community water model in Bui Division, Cameroon. Another determinant of the willingness to pay for water was seen in the cost of water, that is, the actual amount that an individual is able and willing to pay for water. In the $21^{\text {st }}$ Century which is characterised by increased state involvement and commitment to development in a wide area, it becomes imperative for the population to contribute to their own development using the participatory approach. Therefore, paying for water and water-related services will provide the necessary finances to improve upon the state of water-related infrastructural development in Bui Division in particular and Cameroon as a whole.

\section{RECOMMENDATIONS}

The population should understand that the lack of cooperation and stakeholder participation is detrimental in the proper and efficient functioning of water management committees and the execution of waterrelated community activities. Therefore, the population should be aware that stakeholder participation through their presence and prompt active participation in water-related activities (especially issues of willingness to pay) at all levels will lead to an overall sustainability in the management of water resources in their communities.
The population should be aware that water, while being a social good, is also an economic good which demands a lot of investment in service delivery, monitoring, evaluation and maintenance of water-related infrastructures. As such, the population should address their perceptions of water to reflect water as an economic good, and should devote their finances in paying for water.

The leaders and executive members of the village development associations should be aware that they wield a lot of power and authority over their subjects. As such, they should use their authority to cause the population to adhere to the decision taken in the domain of water management, especially financing of water-related development and paying for service provisions in the water sector.

\section{AUTHOR'S BIOGRAPHY}

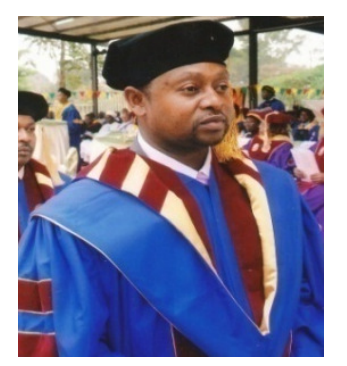

Dr. Robert Njilla Mengnjo Ngalim holds a Bachelor of Science (B.Sc. Hons) Degree, Master of Science (M.Sc.) Degree in Geography with specialisation in Environment and Natural Resource Management and a Doctor of Philosophy (Ph.D.) Degree in Geography with specialisation in Natural Resources Management from the University of Buea, Cameroon. Dr. Njilla is a parttime lecturer in the Department of Geography, University of Buea, the Department of Geography and Planning, the University of Bamenda, and an External Resource Person / Consultant, Department of Development Studies, the Pan African Institute for Development West Africa (PAID-WA), Buea. Dr. Njilla has published several articles in peer-reviewed learned academic journals in Cameroon and abroad. His research interest include aspects such as Applied Physical Geography, Hydrology and Water Resources Management, Geography of Resources and Environmental management, Contemporary Issues in the $21^{\text {st }}$ Century with particular interest in Climate Change related impacts, and Modern Techniques in Geographic Research and Data Analysis, amongst others. Dr. Njilla is also a Freelance Researcher and Consultant on Environmental and Developmental Issues affecting humankind today.

\section{REFERENCES}

Adepoju A.A. and Omonona B.T. (2009). Determinants of Willingness to Pay for Improved Water Supply in Oshogbo Metropolis, Research Journal of Social Sciences, 4, 1-6. (C) 2009, INSInet Publication

Ayanshola, A.M., Sule, B.F. and Salami, A.W. (2013). Evaluation of Willingness to Pay for Reliable and Sustainable Household Water Use in Ilorin, Nigeria. Ethiopian Journal of Environmental Studies and Management Vol. 6 Supplement 2013. Pp. 754- 762. http://dx.doi.org/10.4314/ejesm.v6i6.6S 
Black, M. (1998). Learning What Works, A 20 Year Retrospective View on International Water and Sanitation Cooperation: 1978-1998. Washington, D.C., USA, UNDP-World Bank Water and Sanitation Programme, World Bank.

Cameroon Vision 2035. The Government of Cameroon. Yaounde, Cameroon.

Fondufe, S.L.Y. (2008). Water Supply: Assessment, Management and Rehabilitation in Kumbo Central Sub-Division. Unpublished M.Sc. Thesis, Geography, FSMS, University of Buea, Buea, Cameroon.

GP-DERUDEP (2006). Baseline Study of the North West Province of Cameroon. Sponsored by the African Development Bank \& Government of Cameroon. Elaborated by Society for Initiatives in Rural Development and Environmental Protection (SIRDEP)-Cameroon. GP-DERUDEP: Bamenda. Pp.199.

Haq, M., Mustafa, U. and Ahmad, I. (2007). Household's Willingness to Pay for Safe and Drinking Water: Case Study of Abbottabad District. The Pakistan Development Review 46 (4) part II, 2-10.

Ifabiyi, I.P. (2011). Willingness to Pay For Water at Household Level in Ilorin, Kwara State, Nigeria. Global Journal of Human Social Science, Volume 11 Issue 2 pp. 1 Version 1.0 March 2011. Global Journals Inc. (USA). ISSN: 0975-587x.

Littlefair, K. (1998). Willingness to Pay for Water at the Household Level: Individual Financial Responsibility for Water Consumption. MEWEREW Occasional Paper No.26, Water Issue Study Group, School of Oriental and African Studies (SOAS), University of London, London, UK.

Mbiydzenyuy, H.T. (2011). Improved Watershed Management. Kumbo Watershed: Experience and Lessons Learned. Kivenk Development with assistance from the Canadian Society for Civil Engineering. Gospel Press, Bamenda, Cameroon.

Nana, C. (2012). Research Methods and Applied Statistics. GOOAHEAD: Buea, Cameroon.

Njilla, R.M.N. (2010). Management of Common Property Resources for Sustainable Rural Livelihoods in Bui Division, North West Region of Cameroon. Unpublished M.Sc. Thesis, Department of
Geography, University of Buea, Buea, Cameroon. 215pgs.

Njilla, R.M.N. (2015). The Optimisation of Community Water Management Opportunities in Bui Division, North West Region of Cameroon. Unpublished Ph.D. Thesis, Department of Geography, University of Buea, Buea, Cameroon. 450pgs.

Rogerson, C. (1996). Willingness to Pay for Water: The International Debates, Water SA, 22(4), 73-80.

Tume, S.J.P. (2008). Rainfall Variability and Implication for Water Resources Management: The Case of Bui Division, North West Province of Cameroon. Unpublished M.Sc. Thesis, Department of Geography, University of Buea, Buea, Cameroon.

UNEP (2012). The UN-Water Status Report on the Application of Integrated Approaches to Water Resources Management. United Nations: Washington, D.C.

United Nations (2003). World Population Prospects: The 2002 Revision. Highlights. New York: United Nations.

United Nations Development Programme (2003). Understanding Global Water Distribution. The International Year of Fresh Water. Washington, D.C.

United Nations Development Programme (2006). Water, a Shared Responsibility. World Water Development Report 2. March 2006. Washington, D.C.

United Nations Population Fund (2001). The State of the World Population. Footprints and Milestones Population and Environmental Change, UNFPA: New York.

Whittington, D., Lauria, D. and Mu, X. (1991). A Case Study of Water Vending and Willingness to Pay in Onitsha. World Development, 19(2/3), 179-198.

Whittington, D., Lauria, D., Okun, D., and Mu, X. (1987). An Assessment of Water Vending Activities in Developing Countries, Working Papers No 185 Arlington, VA, Washington.

Zelalem, L. and Beyene, F. (2012). Willingness to Pay for Improved Rural Water Supply in Goro-Gutu District of Eastern Ethiopia: An Application of Contingent Valuation. Journal of Economics and Sustainable Development Vol.3, No.14, 2012. Pp. 145-159. ISSN 2222-1700 (Paper) ISSN 2222-2855 (Online). www.iiste.org 